\title{
o3. Öğretmen adaylarının serbest yazma tutumlarında öğretmen öz yeterlik algılarının yordayıcılı̆̆ı
}

\section{Kayhan BOZGÜN' \\ Fatih CAN ${ }^{2}$}

APA: Bozgün, K.; Can, F. (2021). Öğretmen adaylarının serbest yazma tutumlarında öğretmen öz yeterlik algılarının yordayıcılı̆̆. RumeliDE Dil ve Edebiyat Araştırmaları Dergisi, (24), 21-33. DOI: 10.29000/rumelide.990059.

$\ddot{\mathbf{O z}}$

Öğretmen adaylarının mesleki yaşantılarına başlamadan önce öğretmen öz yeterliklerinin ve serbest yazmaya yönelik tutumlarının belirlenmesi oldukça önemlidir. Öğretmen adaylarının öğretmen öz yeterliklerinin mesleki başarılarını doğrudan etkilediği düşünülmektedir. Ayrıca branş fark etmeksizin öğretmenlerin yazma alışkanlığını ve yazmaya yönelik olumlu tutumunun olması, öğrencilere rol model olarak öğrencilerin yazmaya karşı tutumunu olumlu yönde etkileyerek yazma becerisinin gelişimine de katkı sunabilecektir. Bu araştırma, öğretmen adaylarının iletişim becerilerinde önemli rolü olan serbest yazma tutumlarında öğretmen öz yeterlik algılarının yordayıcılı̆̆ını belirlemeyi amaçlamaktadır. Öğretmen adaylarının serbest yazma tutumları ile öğretmen öz yeterlik algı puanlarının cinsiyet, bölüm ve güncel yayınları okuma değişkenlerine göre farklılaşma durumları incelenmiştir. Araştırma, bir devlet üniversitesinin eğitim fakültesinin 20202021 eğitim-öğretim ylının bahar dönemine kayıtlı farklı bölümlerinde öğrenim gören 454 öğretmen adayının katılımıyla gerçekleştirilmiştir. Verileri toplamak amacıyla "Serbest Yazma Tutum Ölçeği" ile "Ohio Öğretmen Yetkinlik Ölçeği” kullanılmıştır. Verilerin analizleri SPSS 22 programı kullanılarak bağımsız örneklemler $t$-testi, Tek Yönlü Varyans Analizi ve çoklu regresyon analizi ile gerçekleştirilmiş̧tir. Regresyon denklemine hangi değişkenlerin alınması gerektiğini belirlemek amacıyla Pearson Korelasyon analizi bulguları incelenmiştir. Elde edilen bulgularda, öğretmen adaylarının serbest yazma tutumları ve öğretmen öz yeterlik algılarının cinsiyete göre farklılaşmadığı; güncel yayınları okuyanlarda ise anlamlı şekilde farklılaştı̆̆ı belirlenmiştir. Türkçe öğretmenliği bölümü öğretmen adaylarının smnf öğretmenliği ve okul öncesi öğretmenliği bölümü öğretmen adaylarına göre serbest yazma tutumlarının daha yüksek olduğu görülmüştür. Ayrıca öğretmen öz yeterliği yüksek olan, güncel yayınları okuyan ve Türkçe öğretmenliği bölümünde öğrenim gören öğretmen adaylarının serbest yazma tutumlarının daha yüksek olduğu sonucuna varılmıştır.

Anahtar kelimeler: Serbest yazma tutumu, öğretmen öz yeterlik algısı, öğretmen adayları, güncel yayınları okuma

Dr., Arş. Gör. Amasya Üniversitesi, Eğitim Fakültesi, Temel Eğitim Bölümü, Sınıf Eğitim ABD (Amasya, Türkiye), kayhanbozgun@gmail.com, ORCID ID: oooo-0001-9239-2547 [Araştırma makalesi, Makale kayıt tarihi: 16.05.2021kabul tarihi: 20.09.2021; DOI: 10.29000/rumelide.990059]

Dr., Öğr. Üyesi, Amasya Üniversitesi, Eğitim Fakültesi, Türkçe ve Sosyal Bilimler Eğitimi Bölümü, Türkçe Eğitimi ABD (Amasya, Türkiye), fatihcan.fatih@hotmail.com,, ORCID ID: 00oo-0002-9593-2382

Adres $\mid$ Address

RumeliDE Dil ve Edebiyat Araşturmaları Dergisi Osmanağa Mahallesi, Mürver Çiçeği Sokak, No:14/8 Kadıköy - ISTANBUL / TÜRKIYE 34714 e-posta: editor@rumelide.com

RumeliDE Journal of Language and Literature Studies Osmanağa Mahallesi, Mürver Çiçeği Sokak, No:14/8

Kadıköy - ISTANBUL / TURKEY 34714 tel: +90 $5057958124,+902167730616$

e-mail: editor@rumelide.com

phone: +90 5057958124 , +90 2167730616 


\title{
The prediction of pre-service teachers' attitudes of free writing by teacher's self- efficacy perceptions
}

\begin{abstract}
It is significant to determine pre-service teachers' self-efficacy and their attitudes of free writing before begining their professional life. It is considered, teacher self-efficacy directly affects preservice teachers' professional success. In addition, regardless of the branch, all teachers' writing habits and positive attitudes towards writing will contribute to the development of writing skills by positively affecting students' attitudes towards writing as a role model for students. This research delve into determine the predictor of teacher self-efficacy perceptions in attitudes of free writing, which have an important role in pre-service teachers' communication skills. Differences between preservice teachers' attitudes of free writing and teacher self-efficacy perception scores according to gender, department and reading the current publications were examined. The research was carried out with the participation of 454 pre-service teachers studying in different departments of the education faculty of a state university, registered in the spring semester of the 2020-2021 academic year. " Scale to Assess the Free Writing Attitudes " and "Ohio Teacher Efficiacy Scale" were used to collect data. Analysis of the data was carried out by using SPSS 22 program with independent samples t-test, One-way Analysis of Variance and multiple regression analysis. Pearson Correlation analysis findings were examined in order to determine which variables should be included in the regression. According to the findings, the attitudes of free writing of the pre-service teachers and their teacher self-efficacy perceptions did not differ according to gender. It was determined that there was a significant difference in those who read the current publications. It was observed that the attitudes of free writing of the Turkish pre-service teachers were higher than the classroom teaching and preschool teaching pre-service teachers. Also, it was concluded that the attitudes of free writing the preservice teachers who have high teacher self-efficacy perceptions, read current publications and study in the Turkish teaching department are higher.
\end{abstract}

Keywords: Attitudes of free writing, teacher self-efficacy perception, pre-service teachers, reading current publications

\section{Giriş}

Öğretmenin, toplumu yönlendiren ve eğitimin kalitesini belirleyen temel unsur olması nedeniyle sahip olduğu nitelikler oldukça önemlidir (Akdemir vd., 2019). Öğretmenlik, toplumda önemli bir meslek olarak kabul görmektedir. Ancak öğretmenlik mesleğini icra edecek olan bireyde, genel olarak bir bireyin sahip olması gereken temel özelliklerden daha çok öğretmenlik mesleğine yönelik özelliklere sahip olması gerekmektedir. Sürekli değişen ve gelişen şartlara uyum sağlayan ve kendini mesleki yeterliklerle donatan, öğretmenlik mesleğinin gerektirdiği şartlara sahip olan bir bireyin, öğretmenlikte daha başarılı olacağını söylemek mümkündür (Kurt vd., 2013, s. 29). Öğretmenin mesleği ile ilgili yeterlik ve kazanımları sağlaması, öğrenme ortamı üzerinde de birtakım etkileri olacaktır. Öğretmenin mesleğiyle ilgili yeterlikleri, görev ve sorumluklarını da içine almakta; öğretme süreçlerinde başarıya

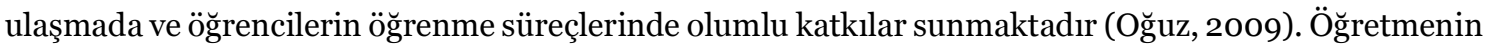
sahip olması gereken bir diğer önemli özellik ise etkili bir iletişim kurabilmesidir. Etkili bir iletişim ancak dili iyi bir şekilde kullanabilmeyle mümkün olabilmektedir. Dil, iletişimi sağlamanın yanı sıra öğrenmede de oldukça önemlidir. Bu yönden bakıldığında dilin iletişim sırasında etkili bir şekilde kullanılması, öğrenme ile de ilişkilidir. Öğrenmede alınan sorumluluk, öğrenme performansını artıran

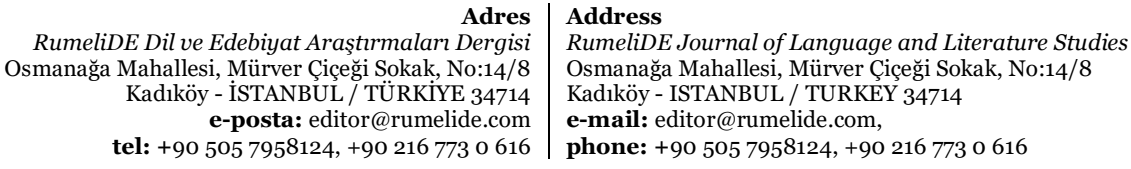


bir unsurdur (Alyılmaz ve Biçer, 2016). Öğretmenler dili iyi kullanabilme ve iletişim kurma gücü bakımından öğrencilere rol model olmalıdır. Bu husus da öğretmenin öz yeterliğinde önemli bir yer teşkil etmektedir.

Öz yeterliği ileri düzeyde olan bir öğretmenin mesleki anlamda gerekli bilgi, beceri ve donanıma sahiptir. Sahip olduğu bu özelliklerle öğretme süreçlerinde karşısına çıkabilecek olumsuz durumlarla baş edebilmesinde, öğrencilerine etkili ve istekli bir öğrenme ortamını oluşturmada başarılı olacaktır (Tüfekçi Aslım ve Kocabatmaz, 2019). Öğretmenlerin, öğretme süreçlerine yönelik sahip oldukları bilgi, beceri ve yeterliklere yönelik algıları oldukça önemlidir. Güçlü bir yeterlik doyumuna sahip bir öğretmenin, öğretme süreçlerinde yönetim, planlama, motivasyon, istek ve çaba konusunda başarılı bir davranış ve tutum sergileyerek öğrencilerin gereksinimlerine yönelik daha uygun bir öğrenme ortamı sağlayacağı; özellikle öğrencilerin öğrenme motivasyonlarını daha ileri seviyeye taşıyacağı söylenebilir (Özdemir, 2008). Bu bağlamda, öğretmenin başarıya ulaşmada gerekli bütün unsurları planlama ve hayata geçirmeye ilişkin inancı, sınıf içi verimliliğini artırarak öğrenci başarısını doğrudan etkileyeceği söylenebilir (Aydın vd., 2014).

Öğretmenin öz yeterlik algısı öğretme ve öğrenme süreçlerini doğrudan etkileyebilmektedir. Çünkü öz yeterlik algısı belirlenen amaçları gerçekleştirme, çaba ve öğrenmeyi etkilemekte ve hedefe odaklanıp performansı etkilemede önemli bir yere sahiptir. Ayrıca öz yeterliği yüksek olan öğretmenin öğrenciler ile daha iyi ilişkiler kurduğu, mevcut ya da olası sorunlarla başa çıkmada başarılı olduğu ileri sürülebilir (Kavrayıcı ve Bayrak, 2016). Dolayısıyla eğitim öğretim süreçlerinde öğretmenin rolü yadsınamaz bir gerçektir. Öğretmenin sahip olduğu mesleki donanım ve algı, öğretme performansına doğrudan ilişkili olarak öğrencinin öğrenme sürecindeki başarısına ve öğrenme algısına etki edebilmektedir. Bu bağlamda olumlu öz yeterlik algısına sahip bir öğretmenin öğrenci üzerinde de olumlu yansımaları olacaktır (Gökdağ Baltaoğlu vd., 2015).

Öğretmenliğin önemli ve vazgeçilmez gereksinimlerinden belki de en önemli olanı iletişimdir. Aslında öğretmenlik, temelde bir iletişim mesleğidir. İletişim çeşitli şekillerde gerçekleşebilmektedir. Ancak kalıcılık sağlaması ve öğrenme süreçlerinde de öne çıkması nedeniyle yazma önemli bir iletişim ve öğrenme - öğretme aracıdır. Öğrenme - öğretme süreçlerinin başlangıcında ve devamında etkili olan yazmanın tanımını şu şekilde yapmak mümkündür: "Yazma, zihnimizdeki duygu, düşünce, istek ve olayların belli kurallara uygun olarak çeşitli sembollerle anlatılması; diğer bir ifadeyle zihinde yapılandırılmış bilgilerin yazıya dökülmesidir.” (Güneş, 2014, s. 157).

Yazma eylemi, karmaşık süreçleri içinde barındırmaktadır. Yazma, uzun süreli bellek, yazma süreci ve etkinlik bileşeninin eşgüdümlü bir biçimde yürütülmesini gerektiren bir eylemdir. Bu anlamda, yazılı bir metin oluşturmak için metnin konusu ile ilgili düşüncelerin üretilmesi, bu düşüncelerin yazıya dökülmesi ve sürekli olarak zihinde üretilenle yazıya aktarılanlar arasındaki bağlantı ve uyumun gözden geçirilmesi işlemleri devam etmektedir. Bu aşamada bellek ve etkinlik çevresi de aktif olarak yazma sürecinin önemli faktörü olarak ortaya çıkmaktadır (Ülper ve Çeliktürk Sezgin, 2019, s. 150).

Yazma eyleminde bazı teknikler bulunmaktadır. Bu tekniklerden biri de serbest yazmadır. Serbest yazma tekniğinde, seçilen bir konu ile ilgili duygu düşünce ve hayal ettiklerini herhangi bir türle sınırlı kalmaksızın yazım gerçekleştirilmektedir. Bu yazım tekniğinde ifade edilecekler hiçbir zihinsel engele takılmadan yazılı olarak ifade edilmektedir. Sınıf içi etkileşimlerin de etkili olduğu bu yazım tekniğinde, genel yazım kurallarına uyularak ve herhangi bir uzunluk ya da kısalık sınırlılığına bağlı kalmadan yazı oluşturulur (Calp, 2013, s. 883). Öğrencilerin öğretmenlerinden bağımsız bir şekilde bir konuda duygu

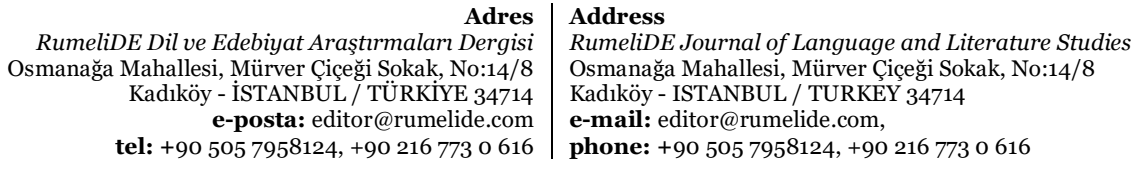


ve düşüncelerini serbestçe dile getirmeleri serbest yazma tekniği olarak adlandırılır (Erdagı Toksun, 2020). Serbest yazı çalışmaları, bireysel gelişim ve eğitim-öğretim süreçlerinde oldukça etkilidir. Bu anlamda bireyin yaşamı boyunca kişisel doyumunu ve eğitim başarısını artırmada serbest yazma faaliyetleri büyük önem taşımaktadır. İlkokul döneminden itibaren başlayan serbest yazma çalışmalarında serbestlik olarak tamamen bir düzensizlik ya da plansızlık yoktur. Serbest yazma çalışmaları, yazılı olarak ifade edilmek istenen duygu ve düşüncelerin yazılı anlatım tekniklerine uygun bir şekilde anlatma esasına dayanır. Bu teknikte, aktarılmak istenenlerin oldukça rahat ve istenen sınırlarda yazıya dökülmesiyle anlatım ve ifade gücünün de artırılmasına zemin hazırlanmış olmaktadır (Göçer, 2014, s. 126-127). Dolayısıyla serbest yazma, bireyin etkili anlatma becerisi kazanma, akıcı bir dil, edebî ve estetik bir zevk kazanma hususunda etkili olmaktadır (Bağcı Ayrancı ve Temizyürek, 2017, s. 706). Aynı zamanda, serbest yazma yaratıcılı̆̆ı geliştiren ve yazma yeteneğinin ortaya çımasında oldukça etkilidir (Aktaş ve Gündüz, 2013, s. 219).

Konu ile ilgili literatüre bakıldığında öğretmen adaylarının öz yeterlik algılarının incelenmesine yönelik yapılmış çalışmalar mevcuttur. Bu çalışmalardan biri Yeşilyurt'un (2013) öğretmen adaylarının öğretmen öz yeterlik algısını belirlemeye yönelik gerçekleştirdiği çalışmadır. Aydın ve diğerlerinin (2014) yaptığı çalışmada, öğretmen adaylarının öz yeterlik algıları ile akademik alanda arzularını erteleme düzeylerine yönelik görüşleri incelenmiştir. Güven ve Gökdağ Baltaoğlu (2017) öğretmen adaylarının öz yeterlik algılarının sahip oldukları öğrenme stilleri ve kullanmış oldukları öğrenme stratejilerini incelemişlerdir. Kurt ve diğerleri ise (2013) öğretimde planlama ve değerlendirme dersinin öğretmen adaylarının öğretmen öz yeterlik algısına olan etkisi araştırmıştır. Baykara (2011), İngilizce öğretmeni adaylarının öğretmen yeterlik algıları ile bilişötesi öğrenme stratejileri arasındaki ilişkiyi belirlemeye yönelik çalışma gerçekleştirmiştir. Akyol (2016) ise öğretmen adaylarının öğrenmeye yönelik motivasyonları ve mesleki öz yeterlik algıları arasındaki ilişkiyi incelemiştir. Korkmaz ve diğerleri (2019), öğretmen adaylarının öğretmen öz yeterlik ve öğretmen girişimcilik özellikleri arasındaki ilişki ve farklılıkları ortaya koymuştur. Yenice (2012) ise öğretmen adaylarının öz yeterlik düzeyleri ile problem çözme becerilerini incelemeye yönelik çalışma gerçekleşirmiştir. İlgili literatürde, öğretmen adaylarının serbest yazmaya yönelik tutumlarının doğrudan incelendiği çalışmaların sınırlı olduğu görülmüştür. Bağcı Ayrancı ve Temizyürek (2017), öğretmen adaylarının serbest yazma tutumlarını belirlemeye yönelik ölçek geliştirmiştir. Aydın ve diğerleri (2013) ise öğretmen adaylarının yazılı anlatım öz yeterliklerini değerlendirmeye yönelik bir ölçme aracı geliştirmiştir. Bağcı Ayrancı (2019) dört kare yazma metodunun eğitim öğretmen adaylarının yazılı anlatım becerisi üzerindeki etkisini ortaya koymuştur. Diğer bir çalışma da Karakuş ve Baki (2017) tarafindan Türkçe öğretmeni ve sınıf öğretmeni adaylarının yazma kavramına ilişkin algılarını ve yazma sürecinde yaşadıkları sorunları belirlemeye yönelik bir çalışmadır. Tan (2020) ise serbest yazmanın yabancı dil olarak İngilizce öğrenen öğrencilerin puanlarına ve tutumlarına olan etkilerini incelemiştir.

Öğretmen öz yeterlik algısına yönelik ve genel olarak öğretmen öz yeterliklerini belirlemeye yönelik ise birçok çalışma literatürde yer almaktadır. Yazma faaliyetleri ve yazmaya karşı tutum, öğretmenlik mesleğinde öğrenme-öğretme süreçlerinde oldukça önemli bir rol oynamaktadır. Bu nedenle öğretmenlik mesleğine başlamadan önce öğretmen adaylarının mesleki öz yeterliğe sahip olması ve mesleki yeterliğe yönelik algılarının olumlu yönde şekillenmesi, öğretme ve öğrenme süreçlerinde başarıya ulaşılmasında oldukça büyük bir öneme sahiptir. Dolayısıyla, öğretmen adaylarının öğretmen öz yeterlikleri ile serbest yazmaya yönelik tutumlarının incelenmesi ayrı bir öneme sahiptir. Gerçekleştirilen bu çalışma, öğretmen adaylarının mesleki yaşantılarına başlamadan önce hem öğretmen öz yeterliklerini belirleme hem de serbest yazmaya yönelik tutumlarını ortaya koyarak alanyazına katkı sunması yönüyle önemlidir.

Adres

RumeliDE Dil ve Edebiyat Araştırmaları Dergis Osmanağa Mahallesi, Mürver Çiçeği Sokak, No:14/8 Kadıköy - ISTANBUL / TÜRKIYE 34714 e-posta: editor@rumelide.com tel: +90 $5057958124,+902167730616$
Address

RumeliDE Journal of Language and Literature Studies

Osmanağa Mahallesi, Mürver Çiçeği Sokak, No:14/8

Kadıköy - ISTANBUL / TURKEY 34714

e-mail: editor@rumelide.com,

phone: +90 $5057958124,+902167730616$ 
Bu araştırmanın amacı, 2020 - 2021 eğitim - öğretim yılı bahar yarıyılında eğitim fakültesinde öğrenim gören öğretmen adaylarının öğretmen öz yeterlikleri ile serbest yazma tutumları arasındaki ilişkiyi ortaya koyarak cinsiyet, güncel yayınları okuma ve öğrenim gördükleri bölümleri gibi çeşitli değişkenlere göre farklılık olup olmadığını belirlemektir. Bu amaca uygun olarak aşağıdaki alt problemlere cevap aranmıştır:

- Öğretmen adaylarının serbest yazma tutum ve öz yeterlik algı puanlarında cinsiyet, bölüm ve güncel yayınları okuma değişkenlerine göre anlamlı farklılık var mıdır?

- Öğretmen adaylarının serbest yazma tutum puanları ile öz yeterlik algı puanları, güncel yayınları okuma ve bölüm değişkenleri (dummy) arasında ilişki var mıdır?

- Öğretmen adaylarının öz yeterlik algı puanları, bölümleri ve güncel yayınları okumaları üstbilişsel farkındalıklarını yordamakta mıdır?

\section{Yöntem}

\section{Araştırma modeli}

Bu araştırma, öğretmen adaylarının serbest yazma tutumlarında öğretmen öz yeterlik algı düzeylerinin yordayıcı rolünün tespit edilmesini amaçlamaktadır. $\mathrm{Bu}$ nedenle araştırmada nicel araştırma yöntemlerinden tarama deseni kullanılmıştır (Cohen, Manion ve Morrison, 2018). Araştırma, genel bir durumu ortaya koyması yönünden betimsel bir nitelik taşımaktadır.

\section{Örneklem}

Öğretmen öz yeterlik algı düzeyleri ölçüldüğü için bu araştırmada öğretmen adaylarından veriler toplanmıştır. Basit rastgele örnekleme yöntemiyle belirlenen örneklem, bir devlet üniversitesinin eğitim fakültesi 2020-2021 akademik yılının bahar döneminde öğrenim gören 454 öğretmen adayından oluşmaktadır. Öğretmen adaylarının cinsiyete göre \%23.6'sı ( $n=107)$ erkek ve \%76.4'ü (n=347) kızdır. Güncel yayınları okuma değişkenine göre \%33'ü ( $n=150)$ takip ettiklerini belirtirken \%67'si $(n=304)$ güncel yayınları okumadıkları yönünde yanıt vermişlerdir. Öğretmen adaylarının \%31.3’ü $(n=142)$ Türkçe öğretmenliği bölümünde, \%36.1’i ( $n=164)$ sinıf öğretmenliği bölümünde, \%20.3’ü ( $n=92)$ okul öğretmenliği bölümünde ve \%12.3’ü $(n=56)$ sosyal bilgiler öğretmenliği bölümünde öğrenim görmektedir.

\section{Verilerin toplanması}

Araştırma verileri cinsiyet, bölüm ve güncel yayınları okuma değişkenlerinden oluşan Demografik Bilgi Formu, serbest yazmaya karşı tutumu belirleyen "Serbest Yazma Tutum Ölçeği” ve öğretimde öz yeterlik algılarını belirleyen "Ohio Öğretmen Yetkinlik Ölçeği” kullanılmıştır. Veriler, gönüllülük esasına göre toplanmıştır. Daha sonra ise veriler, Excel ortamına aktarılmış ve sonrasında SPSS formatına dönüştürülmüştür.

Serbest Yazma Tutum Ölçeği: Bağcı Ayrancı ve Temizyürek (2017) tarafından geliştirilen ve öğretmen adaylarının serbest yazma konusunda tutumlarını ölçmeyi amaçlayan bir ölçektir. Ölçme aracı üç alt boyut ve 19 maddeden oluşmaktadır. Ölçeğin alt boyutları kişinin gelişimine yönelik, yazının gelişimine yönelik ve dış dünyaya yönelik yazma tutumları olarak tanımlanmıştır. Ölçeğin

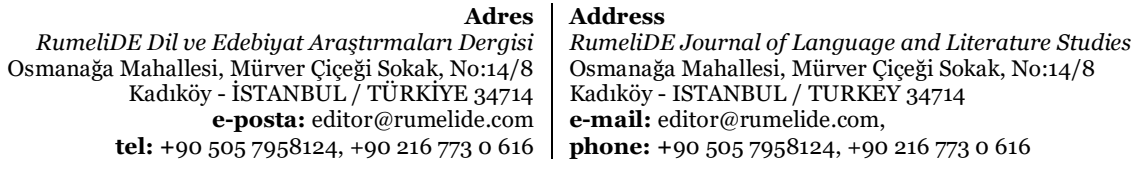


geliştirilmesinde yapı geçerliği Açımlayıcı Faktör analizi (AFA) ile incelenmiştir. Elde edilen sonuçlarda ölçeğin KMO değeri .732; Bartlett testi .05 düzeyinde anlamlı bulunmuştur. Genel güvenirlik analizinde, ölçeğin Cronbach alfa katsayısı .88 olarak hesaplanmıştır. Ölçeğin cevaplanması 1 (kesinlikle katılmıyorum)'dan 5 (kesinlikle katılıyorum)'a doğru 5li Likert tipi derecelendirme anahtarı ile sağlanmaktadır.

Ohio Öğretmen Yetkinlik Ölçeği: Tschannen-Moran ve Woolfolk-Hoy (2001) tarafından geliştirilen ölçeğin Türkçe formunun psikometrik özellikleri Baloğlu ve Karadă̆ (2008) tarafından incelenmiştir. Ölçek 24 maddeden oluşmaktadır. Tuluk (2015) ise ölçeğin yinelenen formunu AFA analizi ile incelemiş ve ölçeği 19 madde, üç alt boyutta toplamıştır. AFA analizlerinde KMO değerinin .944, Bartlett testinin anlamlı olduğu görülmüştür. Üç faktörün toplam varyansın \%53'ünü açıkladığı ve faktör yüklerinin .52 ile .87 arasında değiştiği görülmüştür. Güvenirlik analizinde, iç tutarlık Cronbach alfa katsayısı kullanılarak incelenmiş ve iç tutarlığın .84 ile .93 arasında hesaplandığı belirlenmiştir. Ölçeğin alt boyutları öğrenci yükümlülüğünde öz yeterlik, öğretim uygulamalarında öz yeterlik ve sinıf yönetiminde öz yeterlik olarak adlandırılmaktadır. Ölçekten alınan puanlar 19-95 arasında değişmektedir. Alınan puan yükseldikçe öğretmen veya öğretmen adayının öğretmen öz yeterlik algılarının da yükseldiği yönünde yorum yapılabilmektedir.

\section{Verilerin analizi}

$\mathrm{Bu}$ çalışmanın istatiksel analizleri SPSS 22 programı kullanılarak gerçekleştirilmiştir. Verilerin analizinde öncelikle verilerin doğruluğu, normalliği ve gerçekleştirilen analizlerin varsayımları incelenmiştir. Verilerin normale yakın bir dağılım göstermesini incelemek için örneklem büyüklüğüne göre çarpıklık ve basıklık değerlerinin \pm 2 arasında olduğu ve histogram ve normal Q-Q grafiklerinin normale yakın bir dağılım gösterdiği görülmüştür (Tabachnick ve Fidell, 2014).

Pearson korelasyon ve çoklu regresyon analizinin normallik varsayımı, doğrusallık (korelasyon), regresyon hatalarının normalliği, eş varyanslılık ve çoklu doğrusallık varsayımları (Tabachnick ve Fidell, 2014) için saçılma diyagramları kontrol edilmiş ve verilerin pozitif - negatif doğrusal ilişkiler gösterdiği görülmüsstür. Regresyon hatalarının normale yakın bir dağılım gösterdiği ve eş varyanslılık varsayımının karşılandığ görülmüştür. Bu analizler sonucunda gerçekleştirilmesi planlanan diğer analizler için verilerin uygun olduğu belirlenmiştir.

Öğretmen adaylarının serbest yazma tutum ve öğretmen öz yeterlik algı puanlarının cinsiyete ve güncel yayınları okumalarına göre değişimi bağımsız örneklemler için $t$-testi ile; öğrenim gördükleri bölüme göre değişimi ise tek yönlü varyans analizi (ANOVA) kullanılarak analiz edilmiştir. Bu testlerde varyansların homojenliği, Levene testi ile kontrol edilerek varyansların homojen olduğu görülmüştür. Ayrıca hangi gruplar arasında anlamlı bir fark olduğunu belirlemek için Tukey HSD testi kullanılmıştır. İstatiksel analizlerin tamamında, anlamlılık düzeyi $p<.05$ düzeyinde değerlendirilmiştir.

\section{Bulgular}

\section{Serbest yazma tutumları ve öğretmen öz yeterlik algıları puanlarının demografik değişkenlere göre değişimi}

Öğretmen adaylarının cinsiyet, bölüm ve güncel yayınları okuma değişkenlerine göre serbest yazma tutumları ile öz yeterlik algıları puanlarında anlamlı farklılığı test etmek amacıyla bağımsız gruplar

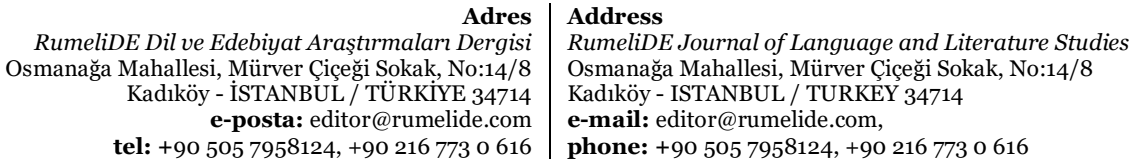


(örneklemler) için $t$-testi ve tek yönlü varyans analizi (ANOVA) gerçekleştirilmiştir. Gerçekleştirilen analiz sonuçları Tablo 1'de görülmektedir.

Tablo 1. Demografik değişkenlere göre bağımsız örneklemler için t-testi ile ANOVA sonuçları

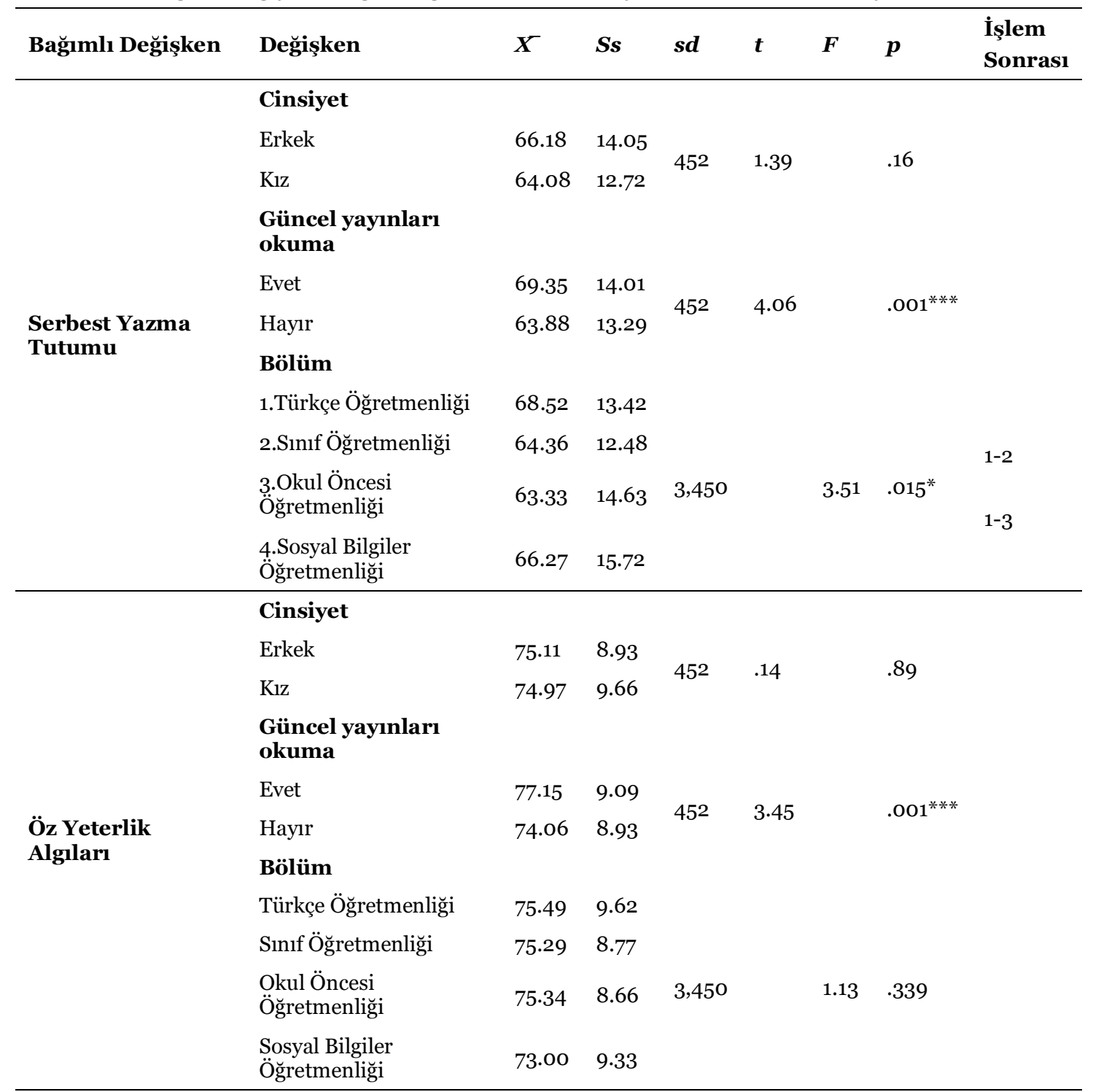

Not: $p<.05^{*} ; p<.001^{* * *}(N=454)$.

Tablo 1'de görüldüğü gibi öğretmen adaylarının cinsiyete göre \%23.6'sı ( $n=107)$ erkek ve \%76.4'ü $(n=347)$ kızdır. Güncel yayınları okuma değişkenine göre \%33’ü $(n=150)$ takip ettiklerini belirtirken \%67'si ( $n=304)$ güncel yayınları okumadıkları yönünde yanıt vermişlerdir. Öğretmen adaylarının \%31.3’ü (n=142) Türkçe Öğretmenliği bölümünde, \%36.1’i (n=164) Sinıf Öğretmenliği bölümünde, \%20.3’ü (n=92) Okul Öğretmenliği bölümünde ve \%12.3’ü (n=56) Sosyal Bilgiler Öğretmenliği bölümünde öğrenim görmektedir.

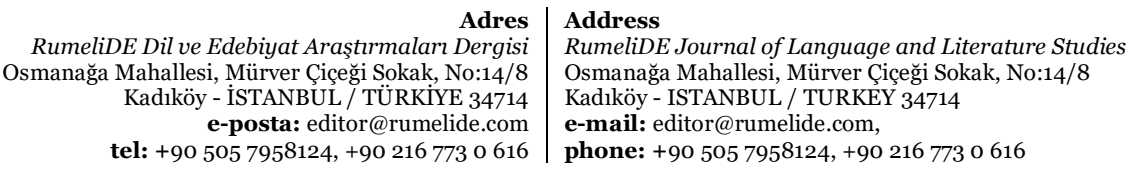


Tablo 1'de ayrıca öğretmen adaylarının serbest yazma tutumları ile öğretmen öz yeterlik algıları puanlarının cinsiyet, güncel yayınları okuma ve öğrenim gördüğü bölümlere göre değişimi bulguları yer almaktadır. Cinsiyet ve Güncel yayınları okuma değişkenleri için bağımsız örneklem $t$-testi gerçekleştirilmiştir. Buna göre öğretmen adaylarının serbest yazma tutum puanları $\left(t\left(45^{2}\right)=1.39, p>\right.$ $.05)$ ile öz yeterlik algıları $(t(452)=.14, p>.05)$ puanlarında erkekler kızlara göre yüksek ortalamalara sahip olmalarına rağmen bu farklılık istatistiki olarak anlamlı değildir. Güncel yayınları okuyan öğretmen adaylarının, Güncel yayınları okumayanlara göre serbest yazma tutum $(t(452)=4.06, p<$ .oo1) ve öz yeterlik algı $(t(452)=3.45, p<$.001) ortalama puanlarının anlamlı bir şekilde daha yüksek olduğu belirlenmiştir. ANOVA analizi sonucunda öğretmen adaylarının öz yeterlik algıları $(F(3,450)=$ 1.13, $p>$.05), öğrenim gördükleri bölüme göre değişim göstermezken Türkçe öğretmenliği öğrencilerinin sınıf öğretmenliği ve okul öncesi öğretmenliği bölümündekilere göre serbest yazma tutum puanlarının farklılaştığı görülmüştür $(F(3,450)=3.51, p<.05)$.

\section{Serbest yazma tutumu ile öğretmen öz yeterlik algıları arasındaki ilişki}

Öğretmen adaylarının serbest yazma tutum puanları ile öğretmen öz yeterlik algısının belirlenmesinde kullanılan “Ohio Öğretmen Yetkinlik Ölçeğı”nin alt boyutları olan öğrenci yükümlülüğünde öz yeterlik, öğretim uygulamalarında öz yeterlik ve sınıf yönetiminde öz yeterlik puanları arasında anlamlı ilişki olup olmadığını test etmek ve regresyon denklemine anlamlı etkisi ortaya çıan hangi demografik değişkenlerin gireceğini belirlemek amaciyla gerçekleştirilen Pearson Korelasyon analizi ile betimsel istatistik sonuçları Tablo 2'de yer almaktadır.

Tablo 2. Değişkenler Arasındaki Korelasyon Değerleri

\begin{tabular}{|c|c|c|c|c|c|c|}
\hline Değişkenler & 1 & 2 & 3 & 4 & 5 & 6 \\
\hline 1. Serbest yazma tutumu & - & & & & & \\
\hline 2. Öğrenci yükümlülüğünde öz yeterlik & $43^{* *}$ & - & & & & \\
\hline 3. Öğretim uygulamalarında öz yeterlik & $.40^{* *}$ & $\cdot 77^{* *}$ & - & & & \\
\hline 4. Sınıf yönetiminde öz yeterlik & $.35^{* *}$ & $.57^{* *}$ & $.66^{* *}$ & - & & \\
\hline 5. Güncel yayınları okuma & $.19^{* *}$ & .15 & $.13^{* *}$ & $.16^{* *}$ & - & \\
\hline 6. Bölüm & $.12^{*}$ & .02 & .05 & $.10^{*}$ & .03 & - \\
\hline $\bar{X}$ & 65.69 & 36.34 & $27 \cdot 48$ & 11.26 & 1.67 & 2.36 \\
\hline Ss & 13.76 & 4.43 & 3.71 & 2.03 & .47 & .94 \\
\hline
\end{tabular}

Not: $p<.05^{*} ; p<.01^{* *}(N=454)$.

Tablo 2'de görüldüğü gibi öğretmen adaylarının serbest yazma tutum puanları ile öğrenci yükümlülüğünde öz yeterlik ( $r=.43, p<.01)$, öğretim uygulamalarında öz yeterlik $(r=.40, p<.01)$ ve sınıf yönetiminde öz yeterlik ( $r=.35, p<.01$ ) puanları arasında pozitif ve orta düzeyde; güncel yayınları okuma değişkeni $(r=.19, p<.01)$ ve bölüm değişkeniyle $(r=.12, p<.05)$ pozitif ve düşük düzeyde ilişki göstermektedir. Bu bulgulara göre, öğretmen adaylarının öz yeterlik algıları artıkça serbest yazma tutumlarının da yükseldiği belirlenmiştir. Öğretmen adaylarının serbest yazma tutum $(X=65.69)$, öğrenci yükümlülüğünde öz yeterlik $\left(X^{\prime}=36.34\right)$, öğretim uygulamalarında öz yeterlik $\left(X^{\prime}=27.48\right)$ ve sınıf yönetiminde öz yeterlik $\left(X^{-}=11.26\right)$ puan ortalamalarının olduğu saptanmıştır. Öğretmen adaylarının serbest yazma tutum puanları ile ilişkili güncel yayınları okuma ve bölüm değişkeni ortalamalarının ve öz yeterlik algı alt boyut puanlarının serbest yazma tutum puanlarıyla ilişkili olup olmadığını saptamak için çoklu regresyon analizi gerçekleştirilmiştir. Tablo 3’te çoklu doğrusal regresyon analizi sonuçları görülmektedir.

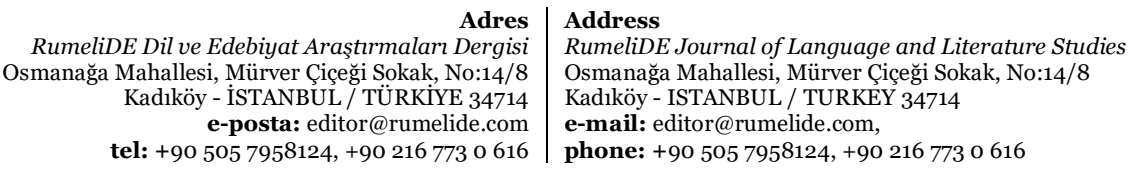




\section{Serbest yazma tutumlarının öğretmen öz yeterlik algılarına göre yordanması-çoklu regresyon analizi}

Tablo 3. Çoklu regresyon analizi sonuçları

\begin{tabular}{|c|c|c|c|c|c|c|c|}
\hline Değişken & $\boldsymbol{B}$ & S.H. & $\boldsymbol{\beta}$ & $t$ & $p$ & İkili $r$ & Kismi $r$ \\
\hline Sabit & 17.04 & 5.83 & - & 2.92 & $.004^{* *}$ & - & - \\
\hline Öğrenci yükümlülüğünde öz yeterlik & .81 & .20 & .26 & 3.98 & $.001^{* * *}$ & .43 & .19 \\
\hline Öğretim uygulamalarında öz yeterlik & .39 & .26 & .11 & 1.48 & .139 & .40 & .07 \\
\hline Sınıf yönetiminde öz yeterlik & .89 & .38 & .13 & 2.35 & $.019^{*}$ & .35 & .11 \\
\hline Güncel yayınları okuma & 3.10 & 1.23 & .11 & 2.52 & $.012^{*}$ & .19 & .12 \\
\hline Bölüm & 1.52 & .51 & .12 & 2.97 & $.003^{* *}$ & .10 & .14 \\
\hline$R^{2}$ & .48 & & & & & & \\
\hline Düz $R^{2}$ & .22 & & & & & & \\
\hline$S H$ & 12.13 & & & & & & \\
\hline$F_{(5,448)}$ & 27.01 & & & & & & \\
\hline
\end{tabular}

Not: $S H:$ Standart Hata, $p<.05^{*} ; p<.01^{* *} ; p<.001^{* * *}$.

Tablo 3’teki çoklu regresyon analizi sonuçlarına göre öğretmen adaylarının serbest yazma tutumları, öz yeterlik algılarının alt boyutları olan öğrenci yükümlülüğ̈̈nde öz yeterlik $(\beta=.26, t(448)=3.98, p<$ .oo1) ve sınıf yönetiminde öz yeterlik $(\beta=.13, t(448)=2.35, p<.05)$ puanları ile orta düzeyde ve anlamlı bir ilişki vermektedir. Ayrıca kukla (dummy) değişkenler olarak regresyon denklemine giren güncel yayınları okuma $(\beta=.11, t(448)=2.52, p<.05)$ ve bölüm $(\beta=.12, t(448)=2.97, p<.01)$ değişkenleri ile öğretmen adaylarının serbest yazma tutum puanları arasında düşük düzeyde ve anlamlı bir ilişkinin olduğu görülmektedir. Standardize edilmiş regresyon katsayısına göre $(\beta)$, serbest yazma tutumlarına yordayıcı değişkenlerin önem düzeyi sırası öğrenci yükümlülüğünde öz yeterlik, sinıf yönetiminde öz yeterlik, öğrenim görülen bölüm ve Güncel yayınları okumaktır. Diğer bir ifadeyle, katılımcılardan güncel yayınları okuyan Türkçe öğretmen adaylarının ve öğrenci yükümlülüğü öz yeterliği ile sınıf yönetimi öz yeterliği yüksek olan öğretmen adaylarının, serbest yazma tutumlarının daha yüksek olduğu görülmüştür. Çoklu regresyon analizi sonucunda öğretmen adaylarının serbest yazma tutumlarının anlamlı birer yordayıcısı olan öz yeterlik algıları puanları ile güncel yayınları okuma ve öğrenim görülen bölüm değişkenlerinin serbest yazma tutumlarındaki toplam varyansın \%22'sini açıladığı görülmüsstür $\left[F(5,448)=27.01, p<.001, \Delta R^{2}=.22\right]$. Öğretmen adaylarının serbest yazma tutumlarının en önemli yordayıcısı öğrenci yükümlülüğü öz yeterlik algılarıdır.

\section{Sonuç ve tartışma}

Araştırmanın "Öğretmen adaylarının serbest yazma tutum ve öz yeterlik algı puanlarında cinsiyet, bölüm ve güncel yayınları okuma değişkenlerine göre anlamlı farklılık var mıdır?” ilk alt problemine göre, öğretmen adaylarının serbest yazma tutumları ile öz yeterlik algıları puanlarının cinsiyete göre değişmediği görülmüştür. Bu bulguyu destekler nitelikte öğretmen adaylarının öğretmen öz yeterlik algılarının (Baykara, 2011) ve serbest yazma tutumlarının (Erdagı Toksun, 2020) cinsiyete göre değişmediğini tespit etmiştir. Güven ve Gökdağ Baltaoğlu (2017) da öz yeterlilik ortalamalarının bölüm değişkenine göre farklılaşmadığı sonucuna ulaşmıştır. Yenice (2012) ise yapmış olduğu çalışmada, öğretmen adaylarının öz yeterlik düzeyleri ile cinsiyetleri arasında anlamlı bir farkın olmadı̆̆ını tespit etmiştir. Cinsiyet olarak bir farklılı̆ın çıkmamasında benzer öğrenme yaşantılarının olması ileri

\footnotetext{
RumeliDE Dil ve Edebiyat Arasturmalari Adres Address

RumeliDE Dil ve Edebiyat Araşturmalar Dergisi $\quad$ RumeliDE Journal of Language and Literature Studies Osmanağa Mahallesi, Mürver Çiçeği Sokak, No:14/8 $\quad$ Osmanağa Mahallesi, Mürver Çiçeği Sokak, No:14/8 Kadıköy - ISTANBUL / TURKIYE 34714 Kadıköy - ISTANBUL / TURKEY 34714 e-posta: editor@rumelide.com e-mail: editor@rumelide.com, tel: +90 505 7958124, +90 2167730616 phone: +90 505 7958124, +90 2167730616
} 
sürülebilir (Nakip ve Özcan, 2016). Kurt ve diğerleri (2013), kız öğretmen adayları yönünde anlamlı bir farklılık gösterdiğini tespit etmiştir. Yeşilyurt (2013) ise farklı olarak erkek öğretmen adaylarının öğretmen öz yeterlik algı düzeyinin kadın öğretmen adaylarının öğretmen öz yeterlik algı düzeyinden daha yüksek olduğunu tespit etmiştir. Bu durumun görülmesinde erkeklerin daha dışa dönük bir yapıda olmasından kaynaklı olduğu söylenebilir. Lule Mert (2016) Türkçe öğretmenliği bölümünün öz yeterlik genel puanı, sınıf öğretmenliğinin öz yeterlik genel puanından yüksek bulunmuştur. Güzel (2014) de bu çalışmadaki bulguları destekler nitelikte Türkçe öğretmeni adaylarının yazmaya yönelik tutumlarının diğer bölümlere göre daha yüksek olduğunu tespit etmiştir. Bu sonuç, Türkçe Öğretmenliği bölümünün müfredat ve ders uygulamaları bakımından yazma faaliyetlerinde daha çok bulunduklarından yazmaya olumlu tutum geliştirmelerini sağlayabileceği söylenebilir. Akyol'un (2016) çalışmasında ise öğretmen öz yeterlik puanlarının yüksek olduğu sonucuna ulaşılmıştır. Güncel yayınları okuyan öğretmen adaylarının serbest yazma tutum puanlarının güncel yayınları okumayan öğretmen adaylarına göre anlamlı bir şekilde daha yüksek olduğu belirlenmiştir. Erdagı ve Toksun'un (2020) da okunan kitap sayısı artıkça serbest yazma tutumunun yükseldiğini belirlemesi bu bulguyu destekler niteliktedir. Ayrıca Türkçe öğretmenliğinde öğrenim gören öğretmen adaylarının sınıf öğretmenliği ve okul öncesi öğretmenliği bölümünde öğrenim gören öğretmen adaylarına göre serbest yazma tutumlarının anlamlı bir şekilde farklılaştı̆̆ı sonucu ortaya çıkmıştır. Bu sonucun ortaya çıkmasında Türkçe öğretmenliği bölümü öğrencilerinin lisans eğitimleri süresinde yazma çalışmaları ve uygulamaları çok sayıda gerçekleştirmiş olmalarının etkili olduğu söylenebilir. Ayrıca Türkçe öğretmenliği bölümü öğrencilerinin bu bölümü tercih etmelerinde yazmaya karşı olumlu tutumlarının olması ve lisans eğitimi süresince de bu yeteneklerini daha açı̆̆a çıkarmalarıyla birlikte diğer bölümlere göre yazma tutumlarının daha iyi olduğu da ileri sürülebilir. Yazmaya olumlu tutumun oluşması, belli bir çabayı gerektirmektedir. Çünkü yazma, kolay olmayan süreçleri içinde barındıran, uygulamayı ve eğitimi gerektiren bir eylemdir (Başar ve Yavaşlı, 2020). Dolayısıyla Türkçe öğretmenliği bölümü öğrencilerinin yazma tutumlarının daha yüksek olmasının beklenen bir sonuç olduğu söylenebilir.

Araştırmanın "Öğretmen adaylarının serbest yazma tutum puanları ile öz yeterlik algı puanları, güncel yayınları okuma ve bölüm değişkenleri arasında ilişki var mıdır?” ikinci alt probleminin bulgularına göre, öğretmen adaylarının serbest yazma tutum puanları ile öğretmen öz yeterlik algı puanları arasında pozitif yönde ve orta düzeyde anlamlı ilişkilerin olduğu tespit edilmiştir. Ayrıca serbest yazma tutum puanları ile güncel yayınları okuma ve öğrenim görülen bölüm değişkenlerinin pozitif yönde düşük düzeyde anlamlı ilişkinin olduğu belirlenmiştir. Öğretmen adaylarının regresyonda yer alacak değişkenler ile ilgili ortalama ve standart sapma istatistikleri bulgularında öğretmen adaylarının öz yeterlik algıları ile serbest yazma tutumu puan ortalamalarının orta düzeyde olduğu söylenebilir. Bulgular yorumlandığında öğretmen adaylarının öz yeterlikleri, birçok yetkinliğin, becerinin kazanılmasında ve öğretimsel davranışların etkili bir şekilde gerçekleşmesinde önemli bir rol oynamaktadır. Bu durum göz önüne alındığında öğretmen adaylarının öz yeterlik algılarının olumlu yönde olması, yazmaya karşı tutumlarının da olumlu yönde gelişimine olanak sunabileceği görülmektedir. $\mathrm{Bu}$ yönden bakıldığında yazmaya karşı olumlu tutumları olan öğretmen adaylarının gelecekte öğrencilerinin yazma becerilerini geliştirmede daha etkili olabileceği söylenebilir. Çünkü yazma becerisinin gelişiminde bireyin tutumun etkili olduğu bilinmektedir. Temizkan ve Sallabaş (2009) da yazmaya yönelik olumlu tutum geliştirmede kişisel ilgi ve tercihlerin önemli olduğunu belirtmiştir. Eğitimin ilk kademelerinde öğrenim gören öğrencilerinin yazma becerilerini geliştirmede daha etkili olabileceği ileri sürülebilir (Ayyıldız ve Bozkurt, 2006). Çünkü yazma becerisinin gelişimi, öğretim dönemlerinin başında gerçekleşmeye başlamaktadır. Bu yönüyle öğretmenlik, mesleki yeterliklerin gerektirdiği şartlara sahip olmak oldukça önemlidir (Kurt vd., 2013). Okuma alışkanlı̆̆ geliştiren ve günlük olarak okumaya çalışan bireylerin yazma becerilerinin daha çok geliştiği yapılan

Adres | Address

RumeliDE Dil ve Edebiyat Araştırmalar Dergisi $\quad$ RumeliDE Journal of Language and Literature Studies

Osmanağa Mahallesi, Mürver Çiçeği Sokak, No:14/8 $\quad$ Osmanağa Mahallesi, Mürver Çiçeği Sokak, No:14/8

Kadıköy - ÍSTANBUL / TÜRKIYE 34714 Kadıköy - ISTANBUL / TURKEY 34714

e-posta: editor@rumelide.com e-mail: editor@rumelide.com,

tel: +90 505 7958124, +90 2167730616 phone: +90 505 7958124, +90 2167730616 
çalışmalardan anlaşılmaktadır (Adler-Kassner ve Estrem, 2007). Bu durum ise öğretmen adaylarının güncel yayınları okudukça yazma becerilerinin gelişimi üzerinde olumlu etkileri olacağını göstermektedir.

Araştırmanın “Öğretmen adaylarının öz yeterlik algı puanları, öğrenim gördükleri bölümler ve güncel yayınları okumaları serbest yazma tutumlarını yordamakta mıdır?” üçüncü alt problemi bulgularına göre, öğretmen adaylarının serbest yazma tutumlarında öz yeterlik algılarının yordayıcılı̆̆ tespit edilmiştir. Öz yeterlik algılarının boyutlarından öğrenci yükümlülüğü öz yeterliği ile sınıf yönetiminde öz yeterlik boyutları anlamlı bir etkiye sahipken öğretimde öz yeterlik algı puanlarının bir etkisi bulunmamaktadır. Ayrıca güncel yayınları okuyan, Türkçe bölümünde öğrenim gören ve öz yeterlikleri yüksek olan öğretmen adaylarının serbest yazma tutumlarının daha yüksek olduğu belirlenmiştir. Bu bulgu ile ilgili alanyazında yapılan çalışmalar incelendiğinde Corkett, Hatt ve Benevides (2011) öğretmenlerin okuma düzeyleri ve öz yeterlik düzeyleri ile yazma becerileri arasında ilişki olduğunu saptamıştır. Güzel (2014) de öğretmen adaylarının yazma tutumlarının bölümlere göre değiştiğini belirlemesi, farklı bölümlerdeki öğretmen adaylarının yazma tutumlarının değişkenlik gösterebildiğini ortaya koymaktadır. Buna göre, öğretmen adaylarının güncel yayınları okumaları teşvik edildiğinde ve öğretmenliğe yönelik öz yeterlik inançları geliştiğinde serbest yazma tutumlarını yükselebileceğini söylemek mümkün olabilir. Öğretmen adaylarının mesleğine yönelik öz yeterlik algılarının olumlu olması, öğretmenlik mesleğinde sahip olmaları gereken becerilerinden biri olan yazmaya karşı olumlu tutuma sahip olabileceğini gösterebilmektedir. Benzer şekilde Karakuş ve Baki'nin (2017) çalışmasında da öğretmen adaylarının yazmaya karşı olumlu tutuma sahip olduğu tespit edilmiştir. Yazmaya yönelik olumlu tutumun oluşmasında, öğretmen adaylarının yazma faaliyetine zaman ayırmalarının etkili olduğu söylenebilir. Bu bakımdan yazmaya yönelik olumsuz tutumların ortadan kalkmasına ve aynı zamanda yazmaya yönelik herhangi bir kaygının oluşmamasında da önemli bir etken olduğu ileri sürülebilir. Bu görüşü destekler nitelikte Tiryaki (2011, s. 138), yazma çalışmalarına daha fazla ağırlık verilerek ve özellikle serbest yazma çalışmaları yapılarak yazma kaygısının ortadan kaldırılabileceğini ileri sürmüştür. Bu yönden bakıldığında serbest yazma, Türkçe öğretmenleri tarafından yazma becerisini geliştirmede en çok kullandıkları stratejilerden biridir (İnnalı ve Aydın, 2018).

Öğretmen adaylarının mesleki hayatlarına başlamadan önce öğretmenliğin gerektirdiği yeterliklere sahip olması önemlidir. Bu bakımdan öğretmenlik uygulaması derslerinin içerik ve yürütülmesinde zenginleştirmeler yapılmalıdır. Ayrıca eğitim ders saatlerinin artırılarak daha çok uygulamaya dönük faaliyetlerin yapılabilir. Bölüm fark etmeksizin tüm öğretmenlerin yazma hususunda gerekli donanıma sahip olması gerekir. Yazmaya yönelik derslerin eğitim fakültesinin tüm bölümlerinde yer alması sağlanarak öğretmen adaylarının yazma konusunda tutum, algı ve yaklaşımlarının olumlu yönde ilerlemesine zemin hazırlanabilir.

\section{Kaynaklar}

Adler-Kassner, L. ve Estrem, H. (2007). Reading practices in the writing classroom. WPA: Writing Program Administration, 31(1-2), 35-47.

Akdemir, E.; Güneri, B. ve Akcaalan, M. (2019). Öğretmen adaylarının öz-yeterlik inancı kaynakları ve yaşama doyumlarının incelenmesi. Turkish Studies - Educational Sciences, 14(5), 2013-2030.

Aktaş, Ş. ve Gündüz, O. (2013). Yazılı ve Sözlü Anlatım. Ankara: Akçă̆.

Akyol, B. (2016). Teacher self-efficacy perceptions, learning oriented motivation, lifelong learning tendencies of candidate teachers: A modeling study. Eurasian Journal of Educational Research, $65,19-34$.

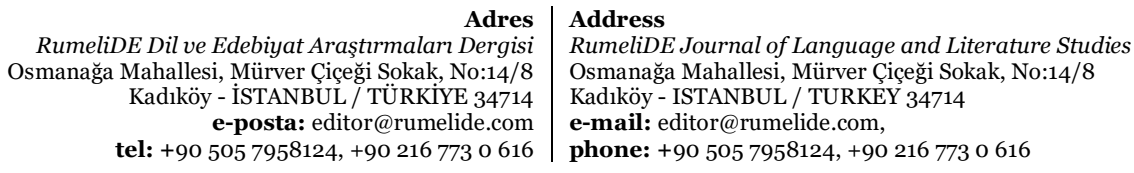


Alyılmaz, C. ve Biçer, N. (2016). Yabancı Dil Olarak Türkçe Öğretiminde Sorumlulukların Öğrenen Özerkliği Bağlamında Değerlendirilmesi. Mustafa Kemal Üniversitesi Sosyal Bilimler Enstitüsü Dergisi, 13(34), 1-23.

Aydın, İ. S.; İnnalı, H. Ö.; Batar, M. ve Çakır, H. (2013). Öğretmen adaylarının yazılı anlatım öz yeterliklerine ilişkin ölçek geliştirme çalışması. Turkish Studies, 8(8), 139-160.

Aydın, R.; Ömür, Y. ve Argon, T. (2014). Öğretmen adaylarının öz yeterlik algıları ile akademik alanda arzularını erteleme düzeylerine yönelik görüşleri. Marmara Üniversitesi Atatürk Ĕ̆itim Fakültesi Ĕ̆itim Bilimleri Dergisi, 4O(40), 1-12.

Ayyldız, M. ve Bozkurt, Ü. (2006). Edebiyat ve kompozisyon eğitimde karşılaşılan sorunlar. Türk Ĕgitim Bilimleri Dergisi, 4(1), 45-54.

Bağcı Ayrancı, B. (2019). Yazılı anlatım becerisi ile dört kare yazma metoduyla yazma becerisinin ilişkisel değerlendirmesi. Türkiye Sosyal Araştırmalar Dergisi, 23(3), 881-891.

Bağcı Ayrancı, B. ve Temizyürek, F. (2017). Eğitim fakültesi öğrencilerinin serbest yazma tutumlarına dair ölçek geliştirme. Ana Dili Ĕ̆itimi Dergisi, 5(4), 704-716.

Baloğlu, N., \& Karadă̆, E. (2008). Öğretmen yetkinliğinin tarihsel gelişimi ve Ohio öğretmen yetkinlik ölçeği: Türk kültürüne uyarlama, dil geçerliği ve faktör yapısının incelenmesi. Kuram ve Uygulamada Ĕ̆itim Yönetimi, 56(56), 571-606.

Başar, T. ve Yavaşlı, M. (2020). Yazarlık ve Yazma Becerileri Dersi Öğretim Programı'nın Öğretmen Görüssleri Doğrultusunda Değerlendirilmesi. Yazarlık ve yazma becerileri dersi öğretim programı'na yönelik öğretmen görüşleri. Ana Dili Ĕ̆itimi Dergisi, 8(2), 270-291.

Baykara, K. (2011). Öğretmen adaylarının bilişötesi öğrenme stratejileri ile öğretmen yeterlik algıları üzerine bir çalışma. Hacettepe Üniversitesi Ĕ̆itim Fakültesi Dergisi, 40, 80-92.

Calp, M. (2013). Serbest ve yaratıcı yazma tekniğine göre oluşturulan kompozisyonların yazılı anlatımın niteliği ve puanlama tekniği açısından karşılaştırılması. Turkish Studies, 8(9), 879-898.

Cohen, L., Manion, L. ve Morrison, K. (2018). Research methods in education (8th ed., p. 218). New York: Routledge.

Corkett, J., Hatt, B. ve Benevides, T. (2011). Student and teacher self-efficacy and the connection to reading and writing. Canadian Journal of Education, 34(1), 65-98.

Erdag1 Toksun, S. (2020). An analysis on attitudes and opinions of candidate teachers of turkish language on free-writing. International Online Journal of Educational Sciences, 12(5), 23-36.

Göçer, A. (2014). Yazma eğitimi. Ankara: Pegem Akademi.

Gökdağ Baltaoğlu, M., Sucuoğlu, H. ve Yurdabakan, İ. (2015). Öğretmen adaylarının öz-yeterlik algıları ve başarı/başarısızlık yüklemeleri: Boylamsal bir araştırma. İlköğretim Online, 14(3), 803-814.

Güneş, F. (2014). Türkçe öğretimi - Yaklaşımlar ve Modeller. Ankara: Pegem Akademi.

Güven, M. ve Gökdağ Baltaoğlu, M. (2017). Öğretmen Adaylarının Özyeterlik Algıları, Öğrenme Stilleri ve Öğrenme Stratejilerinin İncelenmesi: Anadolu Üniversitesi Örneği. AJESI - Anadolu Journal of Educational Sciences International, 7(2), 288-337.

Güzel, İ. (2014). Eğitim fakültesi öğrencilerinin okuma tutumları ve yazma tutumları arasındaki ilişki. Yüksek Lisans Tezi, Malatya: İnönü Üniversitesi Eğitim Bilimleri Enstitüsü.

İnnalı, H. Ö. ve Aydın, İ. S. (2018). Yazma stratejilerinin öğretimine yönelik öğretmen görüşlerinin incelenmesi. Turkish Studies - Educational Sciences, 13(27), 879-889.

Karakuş, N. ve Baki, Y. (2017). Öğretmen adaylarının yazmaya ilişkin algıları ve yazma sürecinde karşlaş̧ıkları güçlükler: RTEÜ örneği. Ahi Evran Üniversitesi Kırşehir Ĕ̆itim Fakültesi Dergisi (KEFAD), 18(1), 573-593.

Kavrayıcı, C. ve Bayrak, C. (2016). Öğretmen adaylarının öz-yeterlik algıları. Adıyaman Üniversitesi Sosyal Bilimler Enstitüsü Dergisi, 23, 623-658.

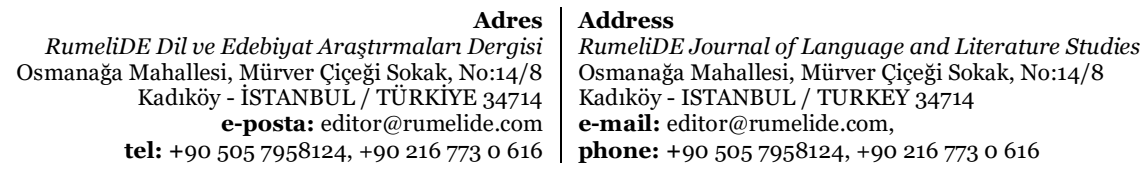


Korkmaz, İ. H.; Çerçi, A. ve Büyükikiz, K. K. (2019). Öğretmen Adaylarının Girişimcilik Özellikleriyle Öğretmen Öz-yeterlikleri Arasındaki İlişkinin İncelenmesi: Gaziantep Üniversitesi Örneği. OPUS Uluslararası Toplum Araştırmaları Dergisi, 13(19), 706-727.

Kurt, H.; Ekici, G.; Aksu, Ö.; Aktaş, M. ve Gökmen, A. (2013). Öğretimde planlama ve değerlendirme dersinin öğretmen adaylarının öğretmen öz-yeterlik algısına etkisinin incelenmesi. Milli Ĕ̆itim, 42(200), 28-48.

Lule Mert, E. (2016). An assessment on self-efficacy of candidate turkish and primary school teachers for teaching profession. Eurasian Journal of Educational Research, 65, 55-70.

Oğuz, A. (2009). Öğretmen adaylarının öz yeterlik inançlarının incelenmesi. Dumlupınar Üniversitesi Sosyal Bilimler Dergisi, 24, 281-290.

Özdemir, S. M. (2008). Sınıf öğretmeni adaylarının öğretim sürecine ilişkin öz-yeterlik inançlarının çeşitli değişkenler açısından incelenmesi. Kuram ve Uygulamada Ĕ̆itim Yönetimi, 14(54), 277306.

Tabachnick, B. G. ve Fidell, L. S. (2014). Using multivariate statistics (6th ed.). Harlow: Pearson Education.

Tan, A. (2020). The impacts of extensive writing on EFL students'attitudes, scores and text readability. Yayımlanmamış Yüksek Lisans Tezi, İstanbul: Bahçeşehir Üniversitesi Eğitim Bilimleri Enstitüsü.

Temizkan, M. ve Sallabaş, M. E. (2009). Öğretmen adaylarının okuma ve yazmaya yönelik tutumlarının karşılaştırılması. Elektronik Sosyal Bilimler Dergisi, 8(27), 155-176.

Tiryaki, E. N. (2011). Üniversite öğrencilerinin tartışmacı metin yazma becerileri ile yazma kaygısı ve eleştirel düsünme becerileri. Yayımlanmamış Yüksek Lisans Tezi, Hatay: Mustafa Kemal Üniversitesi Sosyal Bilimler Enstitüsü.

Tschannen-Moran, M. ve Hoy, A. W. (2001). Teacher efficacy: Capturing an elusive construct. Teaching and teacher education, $17(7), 783-805$.

Tuluk, G. (2015). Öğretmen adaylarının öğretmen öz-yeterlilikleri üzerine bir inceleme. Uşak Üniversitesi Ĕ̆itim Araşttrmaları Dergisi, 1(1), 1-15.

Tüfekçi Aslım, S. ve Kocabatmaz, H. (2019). The relationship between teacher candidates' self-efficacy levels and lifelong learning tendencies. Uluslararası Ĕ̆itim Programları ve Öğretim Çalışmaları Dergisi, 9(1), 179-202.

Ülper, H. ve Çeliktürk Sezgin, Z. (2019). Eğitim fakültesi öğrencilerinin yazma alışkanlığı profillerinin belirlenmesi. Mehmet Akif Ersoy Üniversitesi Eğitim Fakültesi Dergisi, 1(49), 149-170.

Yenice, N. (2012). Öğretmen adaylarının öz-yeterlik düzeyleri ile problem çözme becerilerinin incelenmesi. Elektronik Sosyal Bilimler Dergisi, 11(39), 36-58.

Yeşilyurt, E. (2013). Öğretmen adaylarının öğretmen öz-yeterlik algıları. Elektronik Sosyal Bilimler Dergisi, 12(45), 88-104.

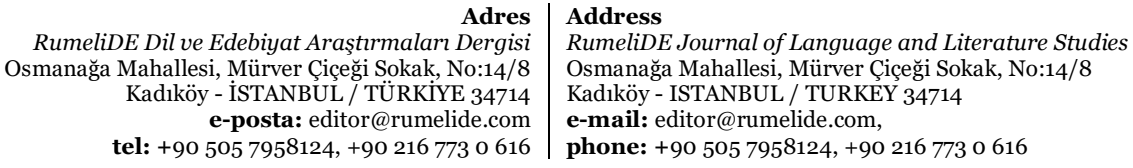

